\title{
Fellhanera scottii sp. nov. (Pilocarpaceae), a new corticolous lichen from Bermuda
}

\author{
Franz Berger*
}

\author{
Article info \\ Received: 30 Jul. 2021 \\ Revision received: 11 Oct. 2021 \\ Accepted: 11 Oct. 2021 \\ Published: 31 Dec. 2021 \\ Associate Editor \\ Martin Kukwa
}

\begin{abstract}
Fellhanera scottii is described as a new corticolous lichen from Bermuda. This new species is characterized by its aeruginose excipulum and curious substrate, growing on stilt roots of Rhizophora mangle.
\end{abstract}

Key words: mangroves, Rhizophora

\section{Introduction}

The genus Fellhanera comprises at least 113 species of discocarpous lichens in the Pilocarpaceae (http://www. indexfungorum.org/names/Names.asp, last consultation 31.7.2021). These lichens mostly occur in tropical and subtropical latitudes, where they are mostly found growing on evergreen leaves. Species of temperate regions are more likely to grow on bark or rock. The genus was introduced by Vězda (1986) with major revisions done by Sérusiaux (1996), Lücking (2008) and Harris \& Lendemer (2009). Additionally, single species were described as new to science or recombined into Fellhanera by (in chronological order) Sérusiaux (1990), Vězda \& Kalb (1991), Vězda \& Hafellner (1991), Vězda (1994), Ekman (1996), Aptroot et al. (1998), Sparrius \& Aptroot (2000), Lücking \& Santesson (2001), Lücking et al. (2001), Sérusiaux et al. (2001), Aptroot (2002), Lücking et al. (2004), van den Boom (2004, 2021), Seaward \& Aptroot (2004), Llop (2007), Elix (2008), Harris \& Lendemer (2009), Sérusiaux \& Brand in Lumbsch et al. (2011), Kondratyuk et al. (2013), Morse \& Ladd (2013), Aptroot \& Cáceres (2014), van den Boom \& Sipman (2014), Kalb (2016), Weerakon et al. (2016), Cacéres \& Aptroot (2017), Elix \& McCarthy (2017), Etayo (2017) and van den Boom (2021).

Fellhanera is characterized by a crustose thallus with a chlorococcoid photobiont and apothecia that are mostly sessile, biatorine, and of variable color. The excipulum is mostly paraplectenchymatous; the paraphyses are sparingly branched; the asci have a $\mathrm{KI}+$ tholus of the Byssoloma-type (Hafellner 1984); and the ascospores are

Raiffeisenweg 130, A 4794 Kopfing, Austria ORCID: 0000-0002-8944-3312

* Corresponding author e-mail: flechten.berger@aon.at hyaline and transversely septate, rarely aseptate or even muriform. The pycnidia usually produce tiny, bacilliform to pyriform conidia.

As part of an ongoing study of Bermudian lichens by Scott LaGreca and the author, an unknown lichen was collected in 2005 and recognized as an undescribed species of Fellhanera.

Bermuda is a group of $\sim 130$ islands (the 'Bermuda Archipelago') at $32^{\circ} 20^{\prime} \mathrm{N}$ and $64^{\circ} 45^{\prime} \mathrm{W}$, covers $\sim 53.5 \mathrm{~km}^{2}$ and is situated $960 \mathrm{~km}$ offshore from the nearest landmass, North Carolina, USA. The islands are roughly 900,000 years old. Unlike North Carolina, Bermuda is dominated by a subtropical biota due to the effects of the passing Gulf Stream combined with the 'Bermuda High', a semi-permanent area of high atmospheric pressure (Thomas 2004). With 1200 inhabitants $/ \mathrm{km}^{2}$, the Bermudas are hyper-urbanized, their biota under constant threat from development and tourism. In addition, devastating hurricanes periodically ravage the islands, adding further stress to the islands' fragile biodiversity.

The new species was encountered in Paget Marsh Nature Reserve (Paget Parish), one of Bermuda's last remaining undisturbed natural areas, now a protected RAMSAR wetland. Paget Marsh is a pristine acidic peatland of $\sim 10$ hectares that gets flooded only during extreme high tides. The area has escaped the strong development of the surrounding area due to early protection (Thomas 2004). The vegetation contains stands of ancient primeval forest (Bermuda cedar, Juniperus bermudiana; Bermuda palmetto, Sabal bermudana; red mangrove, Rhizophora mangle; wax myrtle, Myrica cerifera; savannah saw-grass, Cladium jamaicense; Bermuda sedge, Carex bermudiana; giant fern, Acrostichum danaeifolium; and others). With 
75 species of lichens (Berger and LaGreca, unpublished data), Paget Marsh is one of the hot spots of diversity in the archipelago, which contains 208 total lichen species (LaGreca \& Berger 2021).

\section{Material and methods}

This paper is based on specimens collected in 2005 by the author, which are deposited in BM as well as the private herbarium of the author (hb Berger). The material was examined with an Olympus VMZ stereomicroscope and an Olympus $\mathrm{BH} 2$ compound microscope with interference contrast connected to a Leica DFC290 digital camera. Microscope sections were cut by hand, mounted in tap water and stained with $10 \% \mathrm{KOH}$ and Lugol's solution.

\section{Taxonomy}

Fellhanera scottii F. Berger sp. nov.

(Figs 1-6)

MycoBank MB 840991

Diagnosis: The main difference between Fellhanera scottii and the most similar species F. azorica (van den Boom 2021) is the apothecia, which in the new species are larger, round or slightly lobate, possess a brown hypothecium and an olive tinged blue inner excipulum, and produce longer ascospores $[(12-) 13-16(-18) \times 3-3.5 \mu \mathrm{m}]$. This new lichen species grows on the bark of stilt roots of Rhizophora mangle.

Type: [Bermuda] Paget Parish, Paget Marsh, on stilt roots of Rhizophora mangle, $1 \mathrm{~m}, 32^{\circ} 17.1^{\prime} \mathrm{N}, 64^{\circ} 46.5^{\prime} \mathrm{W}$, F. Berger 20036, 5.5.2005, (DUKE 0383973 - holotype; hb. Berger 20010 - isotype).

Description. Thallus crustose, irregularly delimited, epiphloeodal, continuous, with a scurfy, farinose or finely gyrate surface (ecorticate), thin (up to $40 \mu \mathrm{m}$ ), pale greenish-grey, with an effuse margin; no distinct layers; chlorococcoid algae occupying most of the thallus, algae cells globose, $6-8 \mu \mathrm{m}$ diam.; prothallus not apparent (Fig. 1). Apothecia sessile, numerous, round, shallowly lobate when older, $0.2-0.3(-0.5) \mathrm{mm}$, young disks seemingly blue-black (due to the color of the bluish-black inner rim), at first concave, later becoming slightly convex and light greyish-brown, margin persistent, slightly prominent, paler than disk, with a fine dark blue line

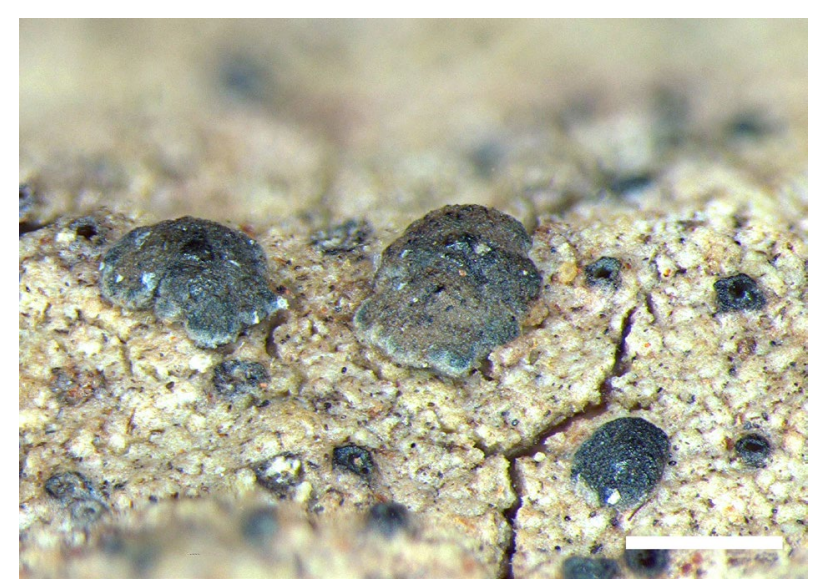

Figure 1. Fellhanera scottii. Thallus with mature apothecia and conidiomata. Scale $=0.3 \mathrm{~mm}$.

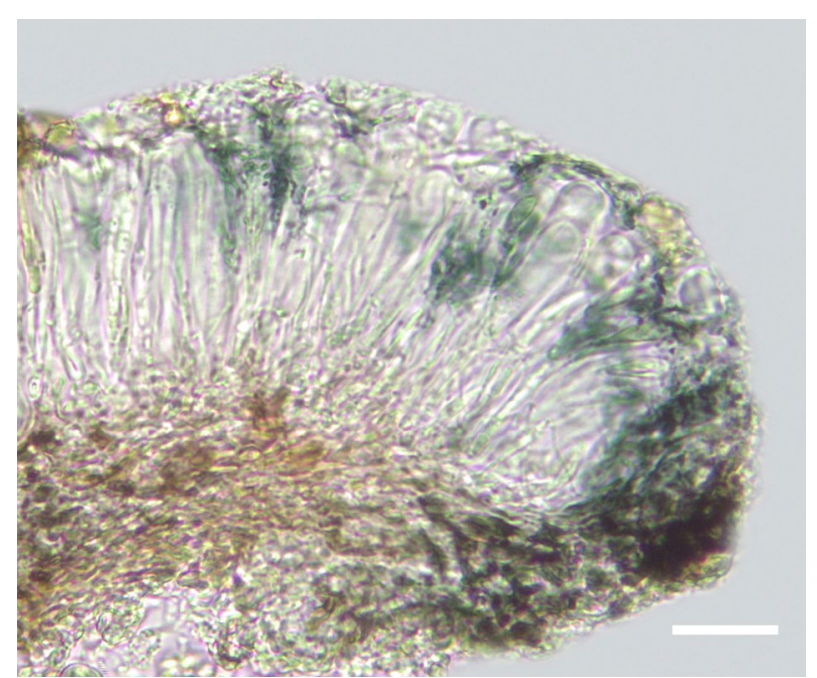

Figure 2. Fellhanera scottii. Cross-section of hymenium in $\mathrm{H}_{2} \mathrm{O}$. Scale $=20 \mu \mathrm{m}$.

persisting (visible stereo-microscopically) at the inner margin (Fig. 1); excipulum biatorine, without algae, without crystals, paraplectenchymatous, inner layer $15 \mu \mathrm{m}$ thick, distinctly blue with slight olive tinge, occasionally mixed with hues of brown at the base (Figs 2-3), outer part of excipulum also $15 \mu \mathrm{m}$ thick, hyaline, paraplectenchymatous, cells thick-walled, 3-7 $\mu \mathrm{m}$ diam., I-, continuing below hypothecium; epihymenium indistinct; hymenium $40-45(-48) \mu \mathrm{m}$ high, hyaline or with aeruginose-blue streaks, I+ blue; hypothecium prosoplectenchymatous, 30-50 $\mu \mathrm{m}$ high, light brown, I+ blue; paraphyses branched, $\sim 1.5 \mu \mathrm{m}$, tips hyaline, slightly clavate; asci fissitunicate, clavate, $32-40 \times 8-10 \mu \mathrm{m}$, with 8 bi- to triseriately arranged ascospores (Fig. 4); tholus KI+ blue, Byssoloma-type, exoascus KI+ blue; ascospores narrowly ellipsoid to fusiform (Fig. 5), apices rounded, hyaline, smooth, 8 per ascus, when mature, 3 -septate, rarely with 5 septa $(<5 \%)$; ascospores not constricted at the septa, with a thin halo, $(12-) 13-16(-18) \times 3-3.5 \mu \mathrm{m}$, length/

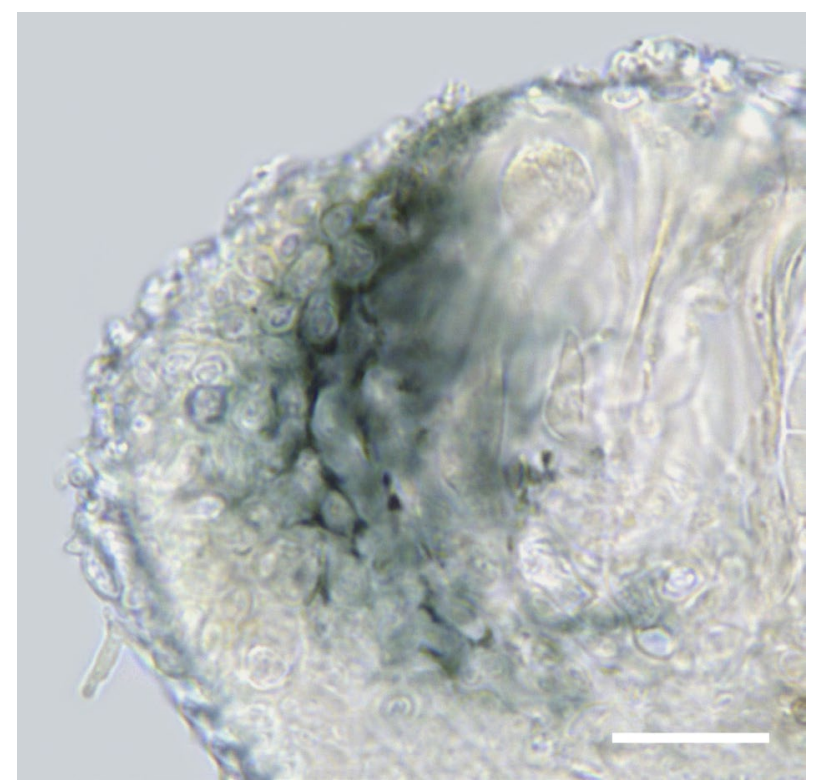

Figure 3. Fellhanera scottii. Cross-section of excipulum, showing the distribution of aeruginous pigments, in $\mathrm{H}_{2} \mathrm{O}$. Scale $=5 \mu \mathrm{m}$. 


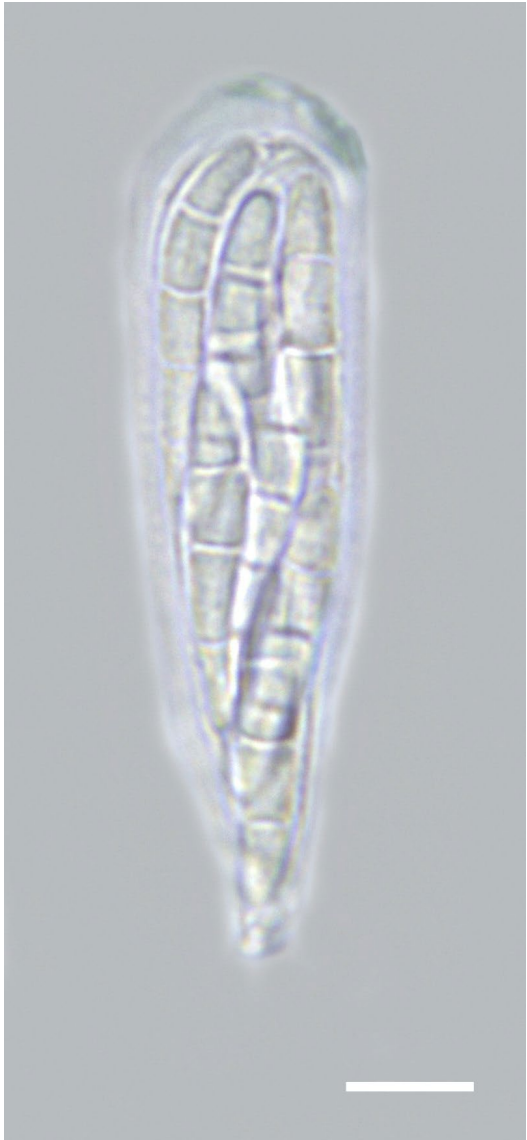

Figure 4. Fellhanera scottii. Ascus with 8 hyaline ascospores in $\mathrm{H}_{2} \mathrm{O}$. Scale $=5 \mu \mathrm{m}$

width ratio $=(2.6-) 4-5(-5.4), \mathrm{n}=35$; conidiomata scattered, superficial, pyriform, bluish black, up to $0.1 \mathrm{~mm}$ wide, conidia bacilliform to fusiform, non-septate, $4 \times$ 1.3-1.7 $\mu \mathrm{m}$ (Fig. 6).

Chemistry. Thallus: $\mathrm{K}-, \mathrm{C}-, \mathrm{KC}-, \mathrm{PD}-, \mathrm{UV}-$. Apothecia: Bluish pigments in excipulum and epihymenium darkening, then turning slowly dark olive in $\mathrm{K}$, brown pigment in hypothecium and basal excipulum $\mathrm{K}$ - and $\mathrm{N}$-; hymenium KI+blue; hypothecium I+ blue, KI-.

Etymology. Named in honour of Dr. Scott LaGreca, lichenologist and collections manager of the W.L. and C.F. Culberson Lichen Herbarium at Duke University, Durham, NC, USA; specifically in recognition of his many taxonomic and floristic contributions to the lichen biota of the Bermudas.

Discussion. According to the last worldwide conspectus of the genus by Sérusiaux (1996), as well as the study of foliicolous species of the Neotropics (Lücking 2008) - and also taking into account new species and new combinations since those works (see chapter 'Introduction') - most species of Fellhanera are foliicolous and thrive in subtropical or tropical habitats. Fellhanera scottii, however, is corticolous and occupies a very special microenvironment - healthy, lower parts of unimmersed stilt roots of red mangroves, just above the humid soil in this inland freshwater swamp. Using the publications of Sérusiaux and Lücking (q.v.), F. scottii keys to foliicolous

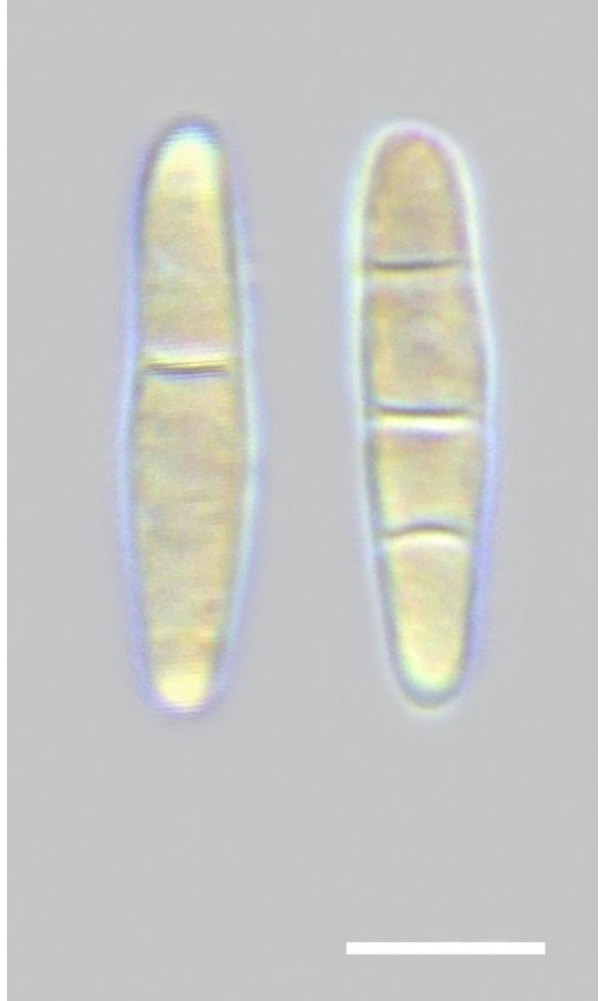

Figure 5. Fellhanera scottii. Ascospores (mainly 3-septate). Scale $=5 \mu \mathrm{m}$.

F. rhapidophylli, a species of the $F$. fuscatula group. Fellhanera rhapidophylli is characterized by a similar thallus structure, but possesses dark greyish- or reddish-brown apothecia and differs in narrower conidia (0.7-1 vs. 1.3$1.7 \mu \mathrm{m})$, as well as a dark rather than a light brown hypothecium. Furthermore, the inner exciple of $F$. scottii

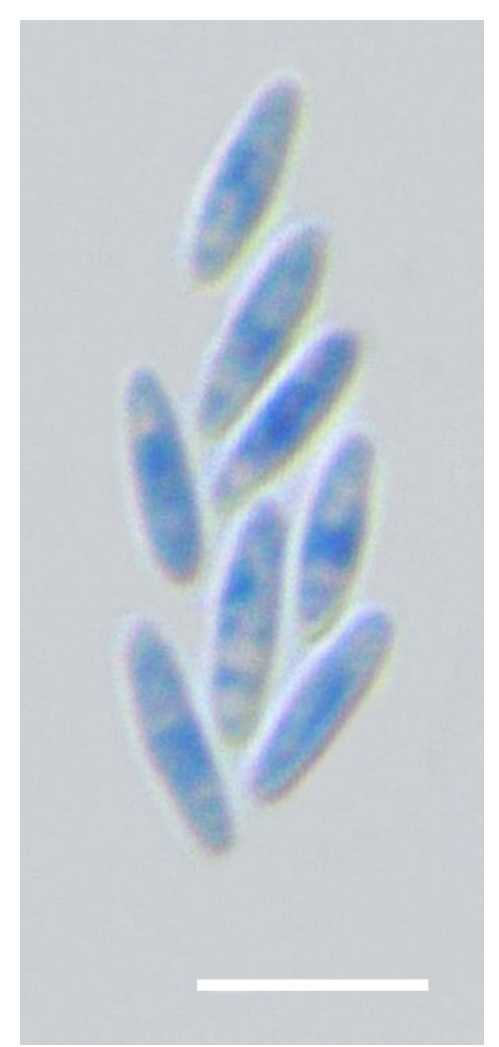

Figure 6. Fellhanera scottii. Conidia in BCR. Scale $=5 \mu \mathrm{m}$. 
is always colored significantly blue with a slight olive tinge, while it is hyaline in F. rhapidophylli (if aeruginous color is observed, it is only present in the marginal exciple (Santesson 1952). The exciple is colored differently in all other species of the genus except the very recently described F. azorica, which grows on leaves of Camelia in the Azores. Fellhanera azorica shares the similarly pigmented exciple of $F$. scotti, but differs in its foliicolous lifestyle, its slightly smaller and always round apothecia, its shorter ascospores (10-)11-12(-14) (2.5-)3.2-4 $\mu \mathrm{m}$ with a lower length/ width ratio (2.5-3 vs. 4-5), and most obviously in its dark blue lower hypothecium, which is light brown in F. scottii. Fellhanera silicis, a species known from chert in North America, is another species with similarly colored epihymenium and outer excipulum, but differs by its thicker, sometimes darker thallus, and its larger (up to $0.5 \mathrm{~mm}$ ), dark brown to black apothecia with concolorous margins, brown inner exciple, and colored paraphyses tips (Harris \& Lendemer 2009).

There is a second Fellhanera on mangroves, F. incolorata, which occurs on the twigs of Avicenna marina in Australia; it cannot, however, be confused with $F$. scottii, as there are no pigments in F. incolorata, and its conidia are drop-like rather than bacilliform (McCarthy \& Elix 2019).

Distribution and ecology. Presumably endemic to the Bermuda Isles and known only from the type location where it occurs on shady parts of the stilt roots of Rhizophora mangle up to one handspan over the humid ground. In this place, Rhizophora mangle does not grow in open salt water, but on the shore of a little pond in a permanent inland freshwater marsh with only underground connections to Bermuda's more typical, tidally-influenced, coastal environment (Thomas 2004). Associated species include Byssoloma leucoblepharum, Bacidina brittoniana and Enterographa multilocularis.

Other specimens examined. Comparative material of Fellhanera azorica: Azores, São Miguel, Ponta Delgada, botanical

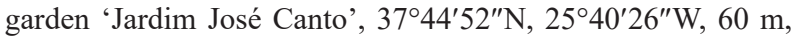
24.10.2011, leg. P. \& B. van den Boom (Hb Boom 46510).

\section{Acknowledgements}

This work was supported by a grant to Franz Berger and Scott LaGreca from the Bermuda Zoological Society. This is contribution number 293 of the Bermuda Biodiversity Project (BBP), Bermuda Aquarium, Natural History Museum and Zoo (BAMZ). Erich Zimmermann is warmly thanked for providing the photographs. Robbie Smith (BAMZ) provided helpful information on the ecology of Paget Marsh. Thanks are also to Robert Lücking (B) for examining material. We also express gratitude to Robert Lücking and Emmanuel Sérusiaux for reviewing and improving the manuscript, and to Pieter van den Boom (Netherlands) for sending material of F. azorica for comparison.

\section{References}

Aptroot, A. 2002. New and interesting lichens and lichenicolous fungi in Brazil. Fungal Diversity 9: 15-45.

Aptroot, A. \& Cáceres, M. E. 2014. New lichen species from termite nests in rainforest in Brazilian Rondônia and adjacent
Amazonas. The Lichenologist 46: 365-372. https://doi.org/10.1017/ s0024282913000340

Aptroot, A., Brand, M. \& Spier, L. 1998. Fellhanera viridisorediata, a new sorediate species of sheltered trees and shrubs in western Europe. The Lichenologist 30: 21-26. https://doi.org/10.1006/ lich.1997.0119

Caceres, M. E. \& Aptroot, A. 2017. Lichens from the Brazilian Amazon, with special reference to the genus Astrothelium. The Bryologist 120: 165-181.

Ekman, S. 1996. The corticolous and lignicolous species of Bacidia and Bacidina in North America. Opera Botanica 127: 1-148.

Elix, J. A. 2008. Four new lichens from tropical and subtropical Australia. Australasian Lichenology 62: 35-40.

Elix, J. A. \& McCarthy, P. M. 2017. Six new lichen species (Ascomycota) from Australia. Telopea 20: 147-163. https://doi.org/10.7751/ telopea 11598

Etayo, J. 2017. Hongos liquenícolas de Ecuador. Opera Lilloana 50: $1-535$.

Hafellner, J. 1984. Studien in Richtung einer natürlichen Gliederung der Sammelfamilien Lecanoraceae und Lecideaceae. Beiheft zur Nova Hedwigia 79: 241-371.

Harris, R. C. \& Lendemer, J. C. 2009. The Fellhanera silicis group in eastern North America. Opuscula Philolichenum 6: 157-174.

Kalb, K. 2016. Lichenes Neotropici XV. Archive for Lichenology 11: 1-12.

Kondratyuk, S., Lőkős, L., Tchabanenko, S., Haji Moniri, M., Farkas, E., Wang, X. Y., Oh, S. O. \& Hur, J. S. 2013. New and noteworthy lichens and lichenicolous fungi. Acta Botanica Hungarica 55(3-4): 275-349. https://doi.org/10.1556/abot.55.2013.3-4.9

LaGreca, S. \& Berger, F. 2021. Checklist of Bermuda lichens \& lichenicolous fungi (under construction). http://bermudalichens.myspecies. info/content/checklist-bermuda-lichens-lichenicolous-fungi-under-construction [accessed 21 January 2021]

Llop, E. 2007. Fellhanera colchica, relocating a forgotten taxon, and Byssoloma llimonae new for Italy. The Lichenologist 39: 393-396. https://doi.org/10.1017/s0024282907007037

Lücking, R. 2008. Foliicolous Lichenized Fungi. Flora Neotropica Monograph 103, The New York Botanical Garden Press, 899 pp.

Lücking, R. \& Santesson, R. 2001. New species or interesting records of foliicolous lichens. VIII. Two new taxa from tropical Africa, with a key to sorediate Fellhanera species. The Lichenologist 33: 111-116. https://doi.org/10.1006/lich.2001.0312

Lücking, R., Cáceres M. E., Kalb, K. \& Sérusiaux, E. 2001. Studies in Bacidia sensu lato (Lichenized Ascomycetes: Lecanorales). II. Six new combinations in Fellhanera Vězda. The Lichenologist 33: 189-194. https://doi.org/10.1006/lich.2000.0318

Lücking, R., Streimann, H. \& Elix, J. A. 2004. Further records of foliicolous lichens and lichenicolous fungi from Australasia, with an updated checklist for continental Australia. The Lichenologist 33: 195-210. https://doi.org/10.1006/lich.2000.0316

Lumbsch, T., Ahti, T., Altermann, S., Arup, U., Kärnefelt, I., Thell, A., et al. 2011. One hundred new species of lichenized fungi: a signature of undiscovered global diversity. Phytotaxa 18: 1-127. https://doi. org/10.11646/phytotaxa.18.1.1

McCarthy, P. M. \& Elix, J. A. 2019. A new saxicolous species of Fellhanera (lichenized Ascomycota, Pilocarpaceae) from eastern New South Wales, Australia. Australasian Lichenology 85: 3-7.

Morse, A. \& Ladd, D. 2013. A new species of Fellhanera (lichenized Ascomycota: Pilocarpaceae) from central North America. The Lichenologist 45: 341-346. https://doi.org/10.1017/ s0024282913000078

Santesson, R. 1952. Foliicolous lichens I. - A revision of the taxonomy of the obligately foliicolous, lichenized fungi. Symbolae botanicae Upsalienses 12(1): 1-590. 
Seaward, M. R. D. \& Aptroot, A. 2004. Four Seychelles lichens new to science. The Lichenologist 36: 119-124. https://doi.org/10.1017/ s002428290401401x

Sérusiaux, E. 1990. Liste préliminaire des lichens et champignons lichénicoles des rochers et éboulis des affleurements du Salmien (Belgique, region de Vielsalm). Mémoires de la Société Royale de Botanique de Belgique 12: 142.

Sérusiaux, E. 1996. Foliicolous lichens from Madeira, with the description of a new genus and two new species and a world-wide key of foliicolous Fellhanera. The Lichenologist 28: 197-227. https:// doi.org/10.1006/lich.1996.0019

Sérusiaux, E., Coppins, B. J., Diederich, P. \& Scheidegger, C. 2001. Fellhanera gyrophorica, a new European species with conspicuous pycnidia. The Lichenologist 33: 285-289. https://doi.org/10.1006/ lich.2001.0328

Sparrius, L. \& Aptroot, A. 2000. Fellhanera ochracea, a new corticolous lichen species from sheltered habitats in western Europe. The Lichenologist 32: 515-520. https://doi.org/10.1006/lich.2000.0292

Thomas, M. L. H. 2004. The Natural History of Bermuda. Bermuda Zoological Society, $255 \mathrm{pp}$.

van den Boom, P. P. G. 2004. Fellhanera. In: Nash III, T. H., Ryan, B. D., Diederich, P., Gries, C. \& Bungartz, F. (eds), Lichen Flora of the Greater Sonoran Desert Region. Vol. 2, pp. 107-108. (Lichens Unlimited, Arizona State University, Tempe)

van den Boom, P. P. G. 2021. Foliicolous lichens and their lichenicolous fungi in Macaronesia and atlantic Europe. Bibliotheca Lichenologica 111: 1-197.

van den Boom, P. P. G. \& Sipman, H. 2014. New or interesting lichen records from Guatemala II - Six new species and records of 80 further taxa. Sydowia 66: 143-168. http://dx.doi.org/10.12905/0380. sydowia66(1)2014-0143

Vězda, A. 1986. Neue Gattungen der Familie Lecideaceae s. lat. (Lichenes). Folia Geobotanica Phytotaxonomica (Praha) 22: 71-83. https://doi.org/10.1007/bf02854668

Vězda, A. 1994. Neue foliicole Flechten II. Nova Hedwigia 58: 123-143.

Vězda, A. \& Hafellner, J. 1991 Beiträge zur Kenntnis der foliikolen Flechten australischer Regenwälder II. Nova Hedwigia 52: 73-80.

Vězda, A. \& Kalb, K.1991. Beiträge zur Kenntnis der foliikolen Flechten australischer Regenwälder III. Nova Hedwigia 53: 215-228.

Weerakoon, G., Wolseley, P. A., Arachchige, O., Da Silva Cáceres, M. E., Jayalal, U. \& Aptroot, A. 2016. Eight new lichen species and 88 new records from Sri Lanka. The Bryologist 119: 131-142. https://doi.org/10.1639/0007-2745-119.2.131 